\title{
Comparing Host Plant Resistance, Engineered Resistance, and Insecticide Treatment for Control of Colorado Potato Beetle and Potato Leafhopper in Potatoes
}

\author{
Gerald M. Ghidiu, ${ }^{1}$ David S. Douches, ${ }^{2}$ Kimberly J. Felcher, ${ }^{2}$ and Joseph J. Coombs ${ }^{2}$ \\ ${ }^{1}$ Department of Entomology, Rutgers, The State University, New Brunswick, NJ 08901, USA \\ ${ }^{2}$ Department of Crop and Soil Sciences, Michigan State University, East Lansing, MI 48824, USA
}

Correspondence should be addressed to David S. Douches, douchesd@msu.edu

Received 15 July 2011; Accepted 19 September 2011

Academic Editor: Kent Burkey

Copyright ( $) 2011$ Gerald M. Ghidiu et al. This is an open access article distributed under the Creative Commons Attribution License, which permits unrestricted use, distribution, and reproduction in any medium, provided the original work is properly cited.

\begin{abstract}
The Colorado potato beetle, Leptinotarsa decemlineata (Say) Order Coleoptera and the potato leafhopper, Empoasca fabae (Harris) Order Homoptera, are the major insect pests of potato in eastern North America. In two years of field trials, we compared the effectiveness of three pest management options for the control of Colorado potato beetle and potato leafhopper: natural host plant resistance (glandular trichomes), engineered resistance (Bacillus thuringiensis [Bt] Berliner cry3A gene) and a susceptible potato cultivar (Superior) with an at-planting application of the insecticide thiamethoxam. Similar and acceptable control of the Colorado potato beetle larvae was obtained with the Bt-cry $3 A$ lines and the thiamethoxam treated "Superior" variety. The glandular trichome cultivar had significantly less Colorado potato beetle damage than did the untreated "Superior" in 2004, although damage was significantly greater than in the Bt-cry3A lines and the insecticide-treated potatoes for both years, and was the only treatment that consistently had very little potato leafhopper damage. These data demonstrate that although each type of host plant resistance mechanism (Bt-cry3A or glandular trichomes) was as effective as the chemical control against one of the insects, neither provides adequate resistance to both Colorado potato beetle and potato leaf hopper.
\end{abstract}

\section{Introduction}

The Colorado potato beetle, Leptinotarsa decemlineata (Say) Order Coleoptera, is considered the most important pest of potatoes throughout the northeastern and mid-Atlantic regions of the United States [1]. Growers rely on pesticides to control Colorado potato beetle in the field but it has developed field resistance to nearly every insecticide used against it and is now resistant to more than 40 chemical insecticides [2].

Another important insect pest of potatoes, the potato leafhopper (Empoasca fabae (Harris) Order Homoptera), is a sap-feeding insect pest that causes damage known as "hopper burn" $[1,3]$. Even low numbers of leafhoppers can cause significant yield losses [4]. In addition, this insect in organic potato fields can cause significant yield losses as there are few control options that are approved for organic production systems [5].

Currently, growers throughout the potato-producing regions of the USA use an at-plant insecticide such as thiamethoxam to control both Colorado potato beetle and potato leafhopper. Although thiamethoxam is systemic, the length of effective protection can vary and additional foliar insecticide sprays may be needed to control midsummer populations of potato leafhopper, thus adding to the cost of production.

Although pesticides are the primary method used to control both Colorado potato beetle and potato leafhopper, other methods of control should be developed and incorporated into a pest management strategy for these insects. Host plant resistance to potato leafhoppers [6] and the Colorado potato beetle [7] has been demonstrated in the wild Bolivian 
Table 1: Densities of small (1st and 2nd instar) and large (3rd and 4th instar) Colorado potato beetle larvae on potato lines in two years (2003 and 2004) of field trials in Bridgeton, NJ.

\begin{tabular}{|c|c|c|c|c|c|c|c|c|c|c|}
\hline \multirow{4}{*}{$\begin{array}{c} \\
\text { Treatment }\end{array}$} & \multicolumn{10}{|c|}{ No. Colorado potato beetle larvae/5 hills ${ }^{\mathrm{a}}$} \\
\hline & \multicolumn{6}{|c|}{2003} & \multicolumn{4}{|c|}{2004} \\
\hline & \multicolumn{2}{|c|}{ July 19 (65 DAP) } & \multicolumn{2}{|c|}{ August 1 (77 DAP) } & \multicolumn{2}{|c|}{ August 8 (84 DAP) } & \multicolumn{2}{|c|}{ June 28 (38 DAP) } & \multicolumn{2}{|c|}{ July 5 (45 DAP) } \\
\hline & $\begin{array}{l}\text { Small } \\
\text { larvae }\end{array}$ & $\begin{array}{l}\text { Large } \\
\text { larvae }\end{array}$ & $\begin{array}{l}\text { Small } \\
\text { larvae }\end{array}$ & $\begin{array}{l}\text { Large } \\
\text { larvae }\end{array}$ & $\begin{array}{l}\text { Small } \\
\text { larvae }\end{array}$ & $\begin{array}{l}\text { Large } \\
\text { larvae }\end{array}$ & $\begin{array}{l}\text { Small } \\
\text { larvae }\end{array}$ & $\begin{array}{l}\text { Large } \\
\text { larvae }\end{array}$ & $\begin{array}{l}\text { Small } \\
\text { larvae }\end{array}$ & $\begin{array}{l}\text { Large } \\
\text { larvae }\end{array}$ \\
\hline "Norwis + Btcry3A" & $0.0 \mathrm{a}$ & $0.0 \mathrm{a}$ & $0.0 \mathrm{a}$ & $0.0 \mathrm{a}$ & $0.0 \mathrm{a}$ & $0.0 \mathrm{a}$ & $0.5 \mathrm{a}$ & $0.8 \mathrm{a}$ & $5.0 \mathrm{ab}$ & $16.3 \mathrm{a}$ \\
\hline "Yukon Gold + Btcry3A" & $1.3 \mathrm{a}$ & $0.0 \mathrm{a}$ & $0.0 \mathrm{a}$ & $0.0 \mathrm{a}$ & $0.3 \mathrm{a}$ & $0.8 \mathrm{a}$ & $0.5 \mathrm{a}$ & $1.5 \mathrm{a}$ & $0.4 \mathrm{a}$ & $8.8 \mathrm{a}$ \\
\hline "Prince Hairy" & $47.8 \mathrm{~b}$ & $17.0 \mathrm{~b}$ & $35.0 \mathrm{~b}$ & $23.0 \mathrm{~b}$ & $8.3 \mathrm{~b}$ & $38.3 \mathrm{~b}$ & $20.5 b$ & $24.5 \mathrm{~b}$ & $10.4 \mathrm{~b}$ & $52.9 \mathrm{~b}$ \\
\hline "Superior" + thiamethoxam & $0.8 \mathrm{a}$ & $0.0 \mathrm{a}$ & $7.5 \mathrm{a}$ & $0.8 \mathrm{a}$ & $2.5 \mathrm{a}$ & $2.3 \mathrm{a}$ & $0.0 \mathrm{a}$ & $0.3 \mathrm{a}$ & $0.0 \mathrm{a}$ & $0.0 \mathrm{a}$ \\
\hline "Superior", untreated & $35.5 b$ & $14.3 \mathrm{~b}$ & $28.0 \mathrm{~b}$ & $16.5 b$ & $11.3 \mathrm{~b}$ & $38.5 \mathrm{~b}$ & $56.5 b$ & $47.0 \mathrm{~b}$ & $11.3 \mathrm{~b}$ & $119.2 \mathrm{c}$ \\
\hline
\end{tabular}

aAP: days after planting.

potato species, Solanum berthaultii Hawkes. This resistance is due to glandular trichomes that exude a viscous fluid, entrapping small arthropods and covering the appendages of larger ones [8]. The potato cultivar "Prince Hairy" (breeding line NYL235-4) was developed at Cornell University through conventional cross-breeding techniques using $S$. berthaultii and in field trials was shown to reduce the number of sprays needed for control of Colorado potato beetle [9].

Another alternative to chemical insecticides is the use of $B t$-based insecticides. The Cry3A delta-endotoxin of Bacillus thuringiensis tenebrionis Berliner $(B t)$ is a microbial protein with specific insecticidal properties against coleopterans but not homopterans [10]. Several potato cultivars have been transformed with the cry3A gene including "Norwis" and "Yukon Gold" [11] which are two important cultivars in Long Island, NY, where Colorado potato beetle pressure is extreme. Although several studies have demonstrated the effectiveness of the $c r y 3 A$ gene against Colorado potato beetle [11-13], none of these studies looked at the effect of the cry $3 A$ gene on potato leafhopper.

In many regions of potato production potato leafhopper and Colorado potato beetle are often found together on potato plants. Therefore, pest management strategies that control both insects are beneficial. Currently, there have been no published studies to evaluate the efficacy of the cry $3 A$ gene against both Colorado potato beetle and potato leafhopper or to compare the efficacy of the $c r y 3 A$ gene with current insecticide regimens used by commercial potato growers. Therefore, this field study compares the effectiveness of natural host plant resistance (glandular trichomes), Bt-cry $3 A$ based resistance, and pesticide-based regimens (thiamethoxam at planting) for the control of both Colorado potato beetle and potato leafhopper.

\section{Materials and Methods}

2.1. Description of Plant Material. Two transgenic potato lines were used in these studies, along with the commercial potato cultivar "Superior" and the cultivar "Prince Hairy."
All were obtained from the breeding program at Michigan State University as seed tubers:

(1) “Norwis + Bt-cry3A" [11];

(2) "Yukon Gold + Bt-cry3A" [11];

(3) "Prince Hairy": variety with glandular trichomes [9];

(4) "Superior": fresh-market potato cultivar; susceptible to potato leafhopper and Colorado potato beetle.

2.2. Experimental Design. Potatoes were planted on 15 April 2003 and on 19 April 2004 at the Rutgers Agricultural Research and Extension Center, Bridgeton, NJ. Prior to planting, lime $\left(2.2 \mathrm{mt} \cdot \mathrm{ha}^{-1}\right)$ and fertilizer $\left(56 \mathrm{~kg} \cdot \mathrm{ha}^{-1} \mathrm{~N}-\mathrm{P}-\right.$ $\mathrm{K})$ were applied and incorporated. The experiment was planted in a randomized complete block design with four replications. Plots consisted of three rows of potatoes. Each row was $7.62 \mathrm{~m}$ long and $0.91 \mathrm{~m}$ wide with seed pieces spaced $22.9 \mathrm{~cm}$ apart within the row. One treatment ("Superior") received a single in-furrow application of thiamethoxam (Platinum 2SC, Syngenta, Greensboro, NC) at planting at a rate of $586.4 \mathrm{~mL} \cdot \mathrm{ha}^{-1}$, applied with a handheld Agway 7.6 liter sprinkler can in a $10.2 \mathrm{~cm}$ band into the seed furrow ahead of the covering hillers; no other treatments received any insecticide applications. A non-insecticide-treated guard row of the cultivar "Superior" buffered each treated row to reduce migration between plots. Postemergence herbicides were applied to all plots according to commercial recommendations [14], and plots were cultivated and irrigated as needed.

2.3. Assessment of Insect Resistance. The numbers of Colorado potato beetle small larvae (1st and 2nd instars) and large larvae (3rd and 4th instars) were counted on three plants in the middle of the center row of each plot after potato beetle population levels developed. The percentage of plant defoliation caused by Colorado potato beetle feeding was measured by visual evaluation (Dr. Ghidiu) on 10 plants in the center of each plot at two to four time points. Potato leafhopper ratings $(0=$ no damage; $1=$ light damage with 
TABLE 2: Percent defoliation of potato plants caused by Colorado potato beetle in two years (2003 and 2004) of field trials in Bridgeton, NJ.

\begin{tabular}{|c|c|c|c|c|c|c|}
\hline \multirow[b]{3}{*}{ Treatment } & \multicolumn{6}{|c|}{$\%$ Defoliation by Colorado potato beetle ${ }^{a}$} \\
\hline & \multicolumn{4}{|c|}{2003} & \multicolumn{2}{|c|}{2004} \\
\hline & $\begin{array}{c}\text { July } 1 \\
\text { (65 DAP) }\end{array}$ & $\begin{array}{c}\text { July } 25 \\
\text { (70 DAP) }\end{array}$ & $\begin{array}{l}\text { August } 9 \\
\text { (85 DAP) }\end{array}$ & $\begin{array}{c}\text { August } 21 \\
\text { (97 DAP) }\end{array}$ & $\begin{array}{c}\text { July } 31 \\
\text { (71 DAP) }\end{array}$ & $\begin{array}{l}\text { August } 8 \\
\text { (79 DAP) }\end{array}$ \\
\hline "Norwis + Btcry3A" & 1a & 1a & $2 \mathrm{a}$ & $18 \mathrm{~b}$ & $3 a$ & $3 a$ \\
\hline "Yukon Gold + Btcry3A" & $2 \mathrm{a}$ & $2 \mathrm{a}$ & $2 \mathrm{a}$ & $3 a$ & $5 a$ & $5 a$ \\
\hline "Prince Hairy" & $19 \mathrm{~b}$ & $22 b$ & $39 b$ & $62 c$ & $19 b$ & $19 b$ \\
\hline "Superior" + thiamethoxam & $3 a$ & $3 a$ & $8 \mathrm{a}$ & $8 \mathrm{a}$ & $6 a$ & $10 \mathrm{ab}$ \\
\hline "Superior", untreated & $19 \mathrm{~b}$ & $24 \mathrm{~b}$ & $59 c$ & $99 d$ & $63 c$ & $99 \mathrm{c}$ \\
\hline
\end{tabular}

${ }^{a}$ DAP: days after planting.

TABLE 3: Potato leafhopper damage rating of potato plants in two years of field trials.

\begin{tabular}{|c|c|c|c|c|c|}
\hline \multirow[b]{3}{*}{ Treatment } & \multicolumn{5}{|c|}{ Potato leafhopper damage rating ${ }^{\mathrm{a}, \mathrm{b}}$} \\
\hline & \multicolumn{2}{|c|}{2003} & \multicolumn{3}{|c|}{2004} \\
\hline & $\begin{array}{l}\text { August } 9 \\
\text { (85 DAP) }\end{array}$ & $\begin{array}{c}\text { August } 21 \\
\text { (97 DAP) }\end{array}$ & $\begin{array}{c}\text { July } 17 \\
\text { (57 DAP) }\end{array}$ & $\begin{array}{c}\text { July } 31 \\
\text { (71 DAP) }\end{array}$ & $\begin{array}{l}\text { August } 8 \\
\text { (78 DAP) }\end{array}$ \\
\hline "Norwis + Btcry $3 A "$ & $1.3 \mathrm{~b}$ & $1.8 \mathrm{~b}$ & $0.9 \mathrm{bc}$ & $2.1 \mathrm{~b}$ & $2.6 \mathrm{~b}$ \\
\hline "Yukon Gold + Btcry3A" & $1.6 \mathrm{~b}$ & $2.9 \mathrm{c}$ & $0.6 \mathrm{~b}$ & $2.2 \mathrm{~b}$ & $2.6 \mathrm{~b}$ \\
\hline "Prince Hairy" & $0.2 \mathrm{a}$ & $0.4 \mathrm{a}$ & $0.2 \mathrm{a}$ & $0.6 \mathrm{a}$ & $1.1 \mathrm{a}$ \\
\hline Superior, untreated & $1.7 \mathrm{~b}$ & $3.0 \mathrm{c}$ & $1.2 \mathrm{c}$ & $2.7 \mathrm{~b}$ & $3.0 \mathrm{~b}$ \\
\hline
\end{tabular}

${ }^{a}$ Damage rating scale: $0=$ no damage; 1 = light damage with off-color leaves, slight curling; 2 = moderate damage, leaves yellowing with heavy curling; 3 = severe damage, leaves brown or dead.

${ }^{\mathrm{b}} \mathrm{DAP}=$ days after planting.

off-color leaves, slight curling; 2 = moderate damage, leaves yellowing with heavy curling; $3=$ severe damage, leaves brown or dead) were recorded on 10 plants in the center of each plot at two to three time points. All data were analyzed using a two-factor analysis of variance [15]. Means separations were determined by application of Tukey's HSD studentized range test [15].

\section{Results}

3.1. Colorado Potato Beetle. Three treatments, "Yukon Gold + Btcry3A," "Norwis + Btcry3A," and "Superior" with thiamethoxam at planting, resulted in significantly fewer small and large (1st-4th instar larvae) Colorado potato beetle larvae at all sampling dates, as compared with "Prince Hairy" (glandular trichomes) and the untreated control (Table 1). There were no significant differences between "Yukon Gold + Btcry3A," "Norwis + Btcry3A," and "Superior" + thiamethoxam for Colorado potato beetle larval counts in both years (Table 1). The same three treatments ("Yukon Gold + Btcry3A," "Norwis + Btcry3A," and "Superior" + thiamethoxam) resulted in significantly less plant defoliation caused by Colorado potato beetle as compared with "Prince Hairy" and the untreated control in both years (Table 2). There were no significant differences between "Yukon Gold + Btcry3A," "Norwis + Btcry3A," and "Superior" + thiamethoxam in either year with the exception of "Norwis + Btcry3A" at 97 DAP (August 21, 2003).
The number of small and large Colorado potato beetle larvae on "Prince Hairy" was not significantly different from the untreated "Superior" in either year with the exception of one sampling date in 2004 (Table 1). However, "Prince Hairy" plants had significantly less defoliation caused by Colorado potato beetle than untreated "Superior" on all evaluation dates in both years, except for the first two sampling dates in 2003 (Table 2). Although "Prince Hairy" demonstrated some resistance to Colorado potato beetle damage, it provided significantly less control than "Yukon Gold + Btcry3A", "Norwis + Btcry3A", and thiamethoxam-treated "Superior" at nearly every sampling date in both 2003 and 2004 (Tables 1 and 2).

3.2. Potato Leafhopper. "Prince Hairy" showed significantly less potato leafhopper damage than other treatments (with the exception of thiamethoxam treated "Superior") in both years (Table 3). "Prince Hairy" plots had a rating of less than 1.1 each year (scale $0-3$ ), demonstrating that this cultivar had little potato leafhopper damage even when the susceptible varieties were severely damaged by leafhopper feeding.

Leafhopper damage to the transgenic lines ("Yukon Gold $+B t c r y 3 A$ " and "Norwis + Btcry3A") was not significantly different from damage to the susceptible cultivar "Superior" in both years with the exception of two sampling dates August 21, 2003 (97 DAP) and July 17, 2004 (57 DAP) (Table 3). Thiamethoxam treatment provided significant control of leafhopper damage in 2004, but in 2003 the 
protection did not last the entire season. By the second sampling date, the damage to the treated plots was not significantly different from the damage to the untreated "Superior" plots (Table 3).

\section{Discussion}

Our results show that both types of host plant resistance were as effective as the chemical control against either the Colorado potato beetle or the potato leafhopper, but neither type provided acceptable control of both insect pests. There is a close linear relationship between leafhopper damage and yield loss $[3,16]$, and Ghidiu (unpublished results) showed that yields begin to decrease as soon as damage starts to appear. Because "Prince Hairy" had significantly less leafhopper damage than the other treatments ("Yukon Gold + Btcry3A," "Norwis + Btcry3A," and untreated "Superior") one would expect less leafhopper-related yield loss with "Prince Hairy" than a more leafhopper-susceptible line. In addition, the use of a glandular trichome line such as "Prince Hairy" may limit the need for pesticide applications to control late season potato leafhopper populations, such as those encountered during the 2003 season, and will be helpful to control this insect in organic production systems.

Although $B t$-based resistance is no longer used in commercial potato production due to consumer resistance to the technology [17], it is important to continue to develop and test new transgenic lines that are insect resistant and meet commercial standards for the various market classes and regional grower preferences. This will ensure that when consumer attitudes change or when the Bt technology is imminently necessary, the appropriate potato cultivars will be available to growers.

\section{Acknowledgments}

The authors thank the farm supervisor, Mr. W. Pompper, and the agricultural technicians for their generous assistance and time helping establish and maintain this project. New Jersey Agricultural Experiment Station publication No. D08-08185-000-09. This paper is supported by state funds and by the United States Hatch Act.

\section{References}

[1] J.L. Capinera, Handbook of Vegetable Pests, Academic Press, New York, NY, USA, 2001.

[2] M. E. Whalon, D. Mota-Sanchez, and P. Bills, The database of arthropods resistant to pesticides, 2005, http://www .pesticideresistance.org/DB/index.html.

[3] E. B. Radcliffe, "Insect pests of potato," Annual Review of Entomology, vol. 27, pp. 173-204, 1982.

[4] A. G. Peterson and A. A. Granovsky, "Relation of Empoasca fabae to hopperburn and yields of potatoes," Journal of Economic Entomology, vol. 43, pp. 484-487, 1950.

[5] A. Seaman, W. M. Tingey, and A. G. Power, "Potato Varietal Mixtures for Potato Leafhopper Management on Organic Farms," New York State Vegetable IPM Project Reports, NYS IPM Publication, 2006.
[6] R. J. Wright, M. B. Dimock, W. M. Tingey, and R. L. Plaisted, "Colorado potato beetle (Coleoptera: Chrysomelidae): expression of resistance in Solanum berthaultii and interspecific potato hybrids," Journal of Economic Entomology, vol. 78, pp. 576-582, 1985.

[7] R. A. Casagrande, "Colorado potato beetle resistance in a wild potato, Solanum berthaultii," Journal of Economic Entomology, vol. 75, pp. 368-372, 1982.

[8] W. M. Tingey and J. E. Laubengayer, "Defense against the green peach aphid and potato leafhoppers by glandular trichomes of Solanum berthaultii," American Journal of Potato Research, vol. 74, pp. 721-725, 1981.

[9] R. L. Plaisted, W. M. Tingey, and J. C. Steffens, "The germplasm release of NYL235-4, a line with resistance to the Colorado potato beetle," American Journal of Potato Research, vol. 69, pp. 843-846, 1992.

[10] G. W. Zehnder and W. D. Gelernter, "Activity of the M-ONE formulation of a new strain of Bacillus thuringiensis against the Colorado potato beetle (Coleoptera: Chrysomelidae): relationship between susceptibility and insect life stage," Journal of Economic Entomology, vol. 82, pp. 756-761, 1989.

[11] J. J. Coombs, D. S. Douches, W. Li, E. J. Grafius, and W. L. Pett, "Combining engineered (Bt-cry3A) and natural resistance mechanisms in potato for control of Colorado potato beetle," Journal of the American Society for Horticultural Science, vol. 127, no. 1, pp. 62-68, 2002.

[12] M. J. Adang, M. S. Brody, G. Cardineau et al., "The reconstruction and expression of a Bacillus thuringiensis cryIIIA gene in protoplasts and potato plants," Plant Molecular Biology, vol. 21, no. 6, pp. 1131-1145, 1993.

[13] D. S. Douches, T. J. Kisha, W. Li, W. L. Pett, and E. J. Grafius, "Effectiveness of natural and engineered host plant resistance in potato to the Colorado potato beetle (Leptinotarsa decemlineata (Say))," HortScience, vol. 36, pp. 967-970, 2001.

[14] Anonymous, "Commercial vegetable production recommendations for New Jersey," in Rutgers NJAES Cooperative Extension, S. A. Garrison, Ed., p. 135, Rutgers, The State University of New Jersey, Rutgers School of Environmental and Biological, New Brunswick, NJ, USA, 2003.

[15] SAS Institute, SAS/STAT User's Guide, Version 8, SAS Institute, Cary, NC, USA, 4th edition, 1990.

[16] L. L. Sanford and R. E. Webb, "Loss of yield in potato selections infested with potato leafhoppers," American Potato Journal, vol. 54, no. 12, pp. 581-586, 1977.

[17] Cropchoice. Monsanto shelves transgenic potatoes, 2001, http://www.cropchoice.com/leadstry6a84.html? recid=266. 


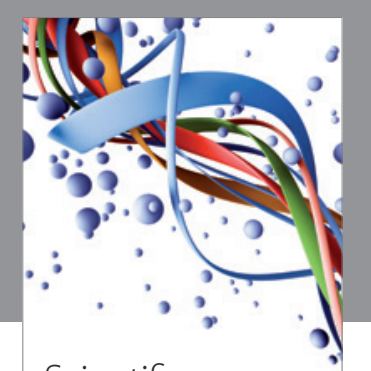

Scientifica
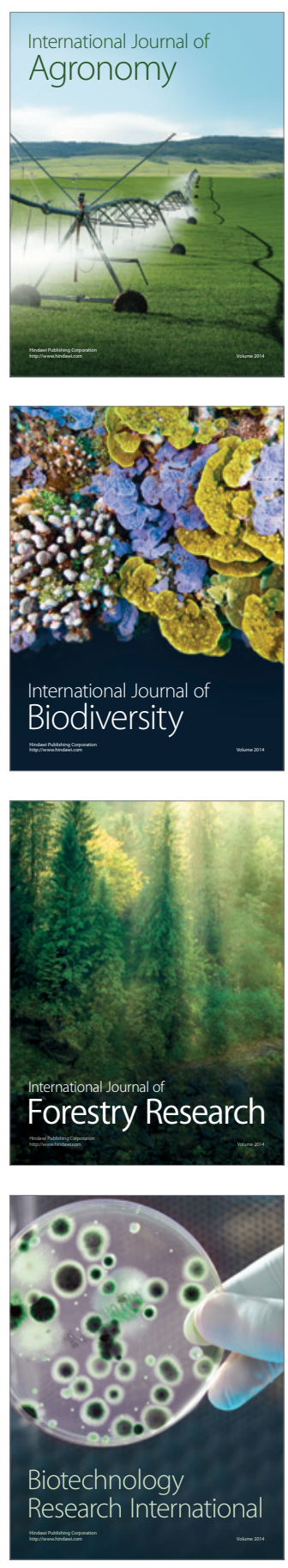
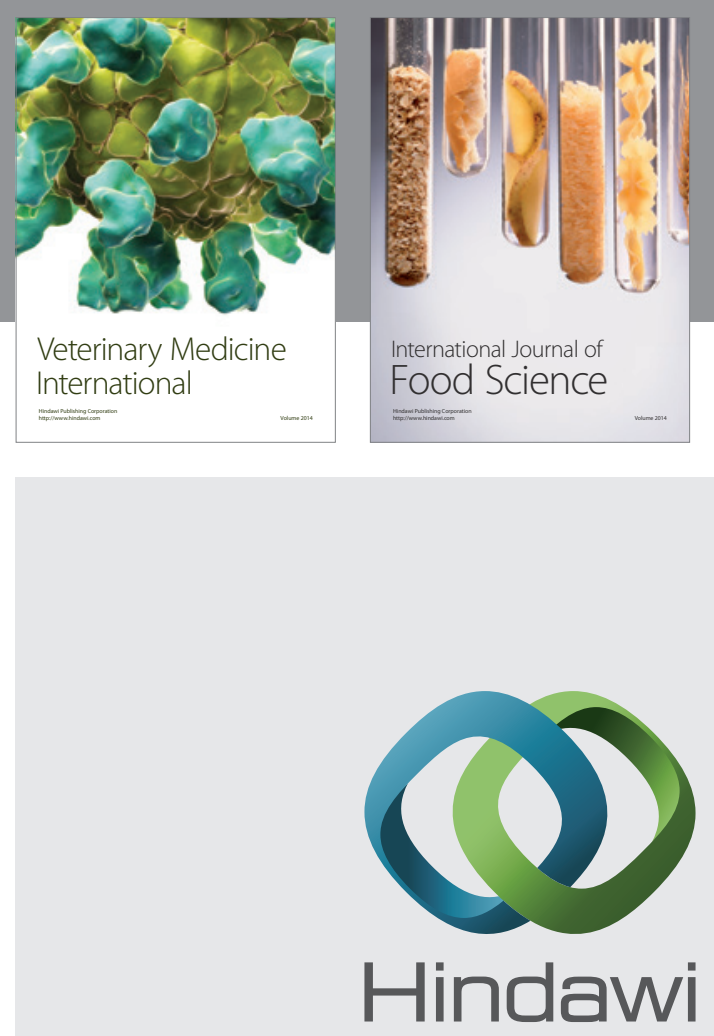

Submit your manuscripts at

http://www.hindawi.com
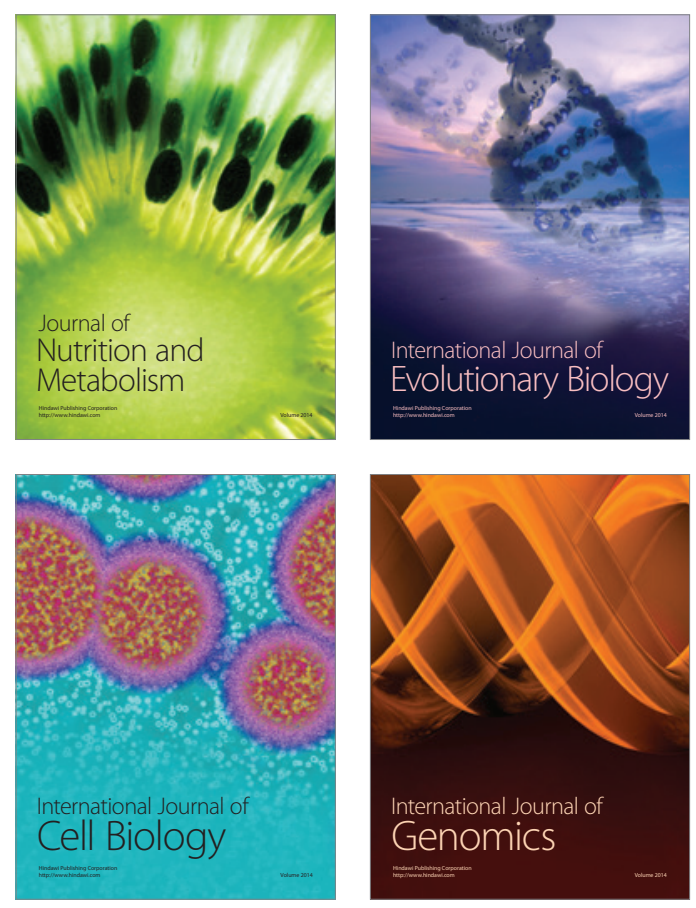
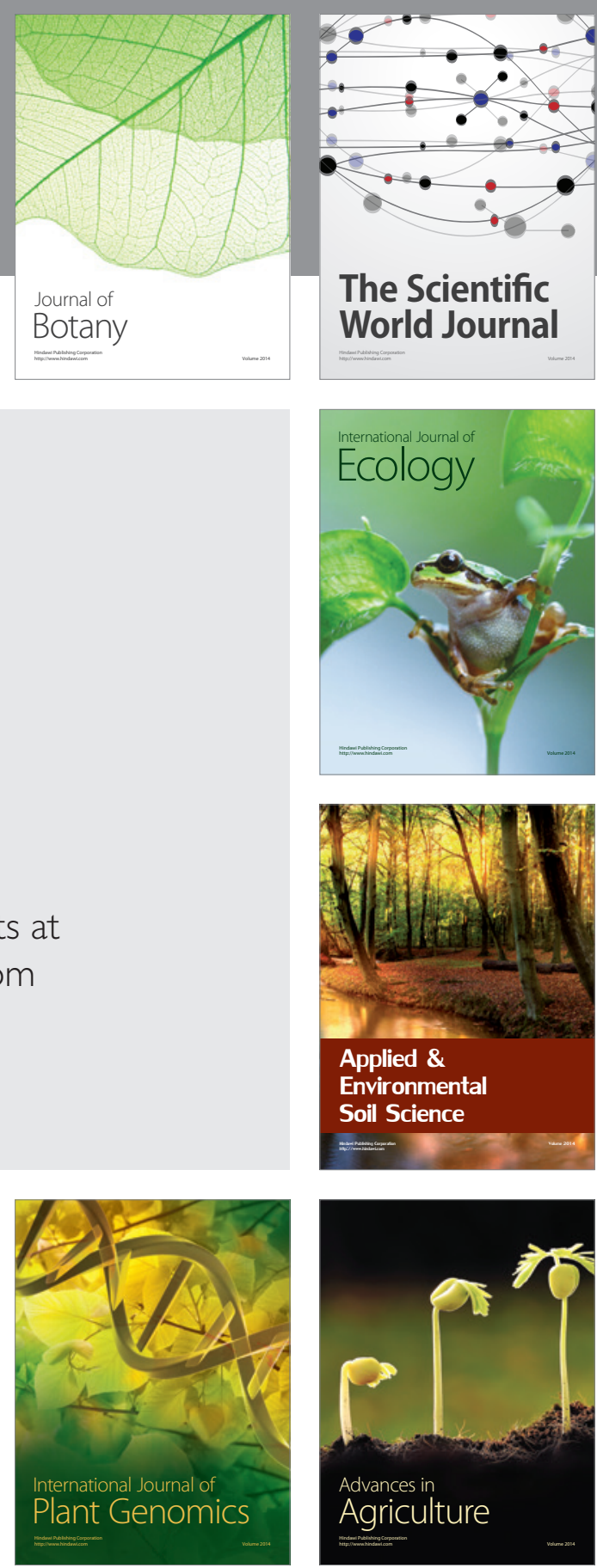

The Scientific World Journal
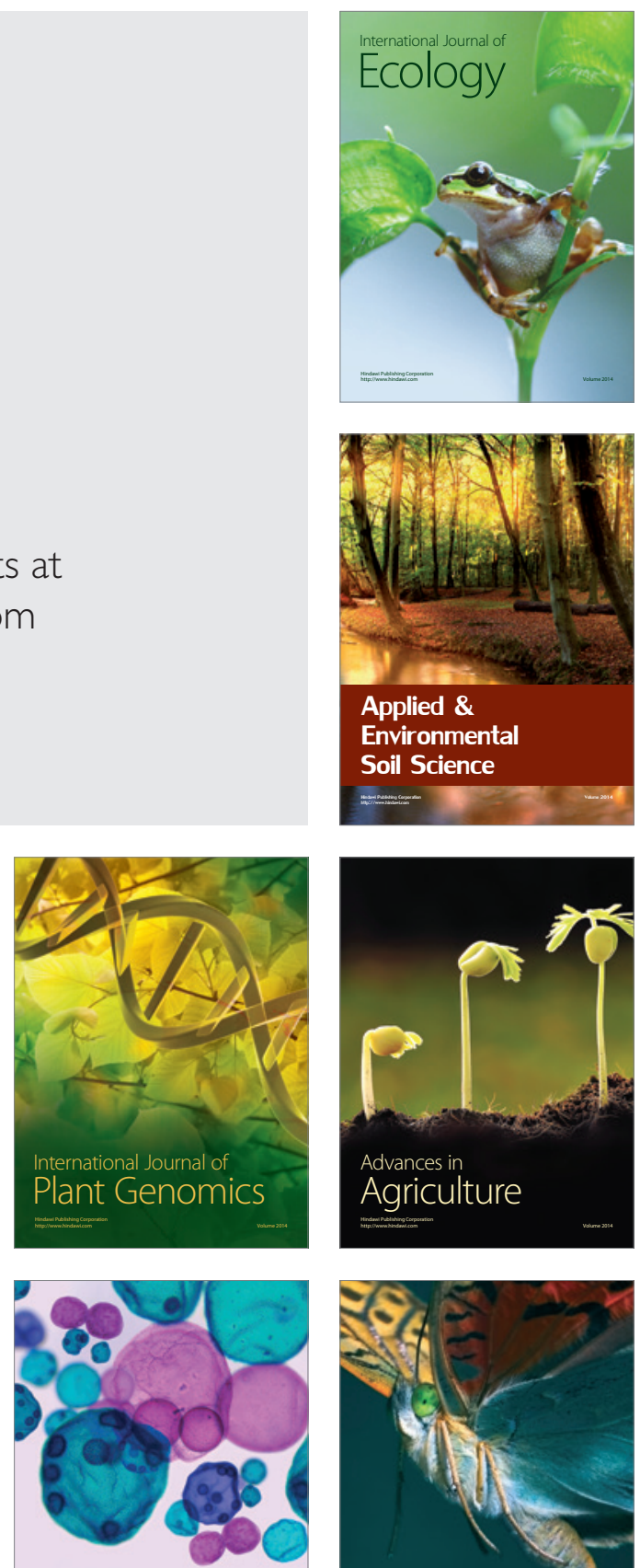

International Journal of Microbiology

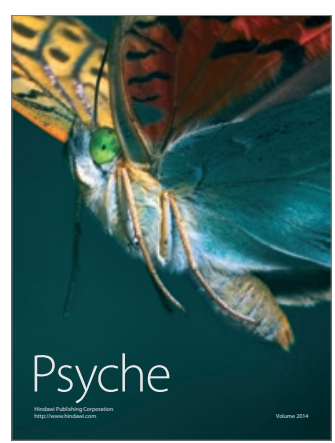

